\title{
Changes in $p m o A$ gene containing methanotrophic population and methane oxidation potential of dry deciduous tropical forest soils
}

\author{
Yashpal Bhardwaj and Suresh Kumar Dubey* \\ Centre of Advanced Study in Botany, Institute of Science, Banaras Hindu University, Varanasi 221 005, India
}

In natural ecosystems such as forests topographical gradients, species composition variability and seasonality, are the potential drivers of methane $\left(\mathrm{CH}_{4}\right)$ metabolism, and thus, of the population size and activities of methane oxidizing bacteria (MOB). To test the hypothesis that topography, tree species and seasonal variability influence MOB population and soil methane oxidation potential (MOP), we conducted two consecutive years of study selecting three sites in a dry deciduous tropical forest in Chandauli district of eastern Uttar Pradesh, India. The qPCR results showed a large variation in MOB population size (copies $\mathrm{g}^{-1} \mathrm{dws}$ ), ranging from $1.0 \times 10^{6}$ to $2.1 \times 10^{7}$ and $9.0 \times 10^{5}$ to $2.2 \times 10^{7}$ during 2016 and 2017 respectively. The distribution of MOB population revealed the trend: hilltop $>$ middle $>$ hillbase with its maxima in the winter and minima in the rainy season. Laboratory incubation study revealed a similar trend in soil MOP (ng $\mathrm{CH}_{4} \mathrm{~g}^{-1} \mathrm{~h}^{-1} \mathrm{dws}$ ), it varied from 10.6 to 20.6 and 10.5 to 20.7 during 2016 and 2017 respectively. The outer canopy soils showed lower MOB population and MOP compared to under canopy soils of tree species Butea monosperma, Madhuca indica and Tectona grandis during both years of study. The topography, season and tree species significantly influenced the MOB population size and MOP. Soil MOP showed a highly significant correlation $(r=0.89 ; p<0.01)$ with MOB population, and a negative correlation was found with soil moisture $(r=0.76 ; p<0.01)$. The results indicate that the dry deciduous tropical forest soils are potential sinks of atmospheric $\mathrm{CH}_{4}$ wherein, the MOB population characteristically responds to topographical changes, tree species and seasonal shifts driving collectively the overall MOP of forest soils.

Keywords: Methanotrophs, topography, season, tree species, tropical dry deciduous forest.

Methane $\left(\mathrm{CH}_{4}\right)$, an important greenhouse gas, contributes to about $20 \%$ of the global warming effects ${ }^{1}$. Since

*For correspondence. (e-mail: skdubey@bhu.ac.in) the beginning of the industrial era (1750) to $2011, \mathrm{CH}_{4}$ concentration has increased from 715 to $1803 \mathrm{ppb}$; with $1 \%$ annual increase over a century ${ }^{2}$. The largest sink (about $90 \%$ of the total $\mathrm{CH}_{4}$ ) is its photochemical oxidation mediated by reactions with hydroxyl $\left(\mathrm{OH}^{-}\right)$radicals ${ }^{3}$. Other significant sinks include diffusion into the stratosphere, and microbial oxidation. Although total $\mathrm{CH}_{4}$ sink strength in terrestrial ecosystems is driven by microbial oxidation in the order $33.5 \pm 0.6 \mathrm{Tg} \mathrm{CH}_{4} / y$ (ref. 4), role of the latter cannot be underestimated as these are important contributors to attenuate $\mathrm{CH}_{4}$ flux at the oxic-anoxic interfaces ${ }^{5}$.

Methane oxidation in aerobic soils is mediated by methanotrophs (methane oxidizing bacteria; MOB), a subgroup of methylotrophs. These bacteria utilize $\mathrm{CH}_{4}$ as the sole carbon and energy source ${ }^{6,7}$. Among terrestrial ecosystems, methanotrophic community inhabiting forest soils has been identified as a major contributor to atmospheric $\mathrm{CH}_{4}$ oxidation ${ }^{8}$. Atmospheric $\mathrm{CH}_{4}$ oxidation studies are mainly confined to temperate forest soils ${ }^{9-11}$, whereas similar reports in tropical and subtropical forest soils, are very limited ${ }^{12-14}$. Some earlier studies suggested that $\mathrm{CH}_{4}$ oxidation potential (MOP) of soils depends on the diffusive gas transport ${ }^{8}$, soil nitrogen content ${ }^{15,16}$, land use $^{17}$, soil temperature ${ }^{18}, \mathrm{pH}^{19}$, salinity ${ }^{20}$, season ${ }^{21}$, topographic positions ${ }^{22}$ and tree species ${ }^{23}$. The $\mathrm{CH}_{4}$ uptake rate studied in temperate forests reported higher values during summer compared to winter ${ }^{21,24}$. In earlier studies, soil moisture and temperature were the key regulatory factors that drive $\mathrm{CH}_{4}$ oxidation in soil. High soil moisture creates barrier for oxygen diffusion into the soil, required by aerobic methanotrophic bacteria, whereas increasing temperature up to optimum level $\left(25-35^{\circ} \mathrm{C}\right)$ enhanced the methanotrophic activity ${ }^{25}$. Methanotrophic population and their activity are also influenced by soil physical properties ${ }^{26}$. Thus it can be assumed that multivariate factors are linked to the regulation of $\mathrm{CH}_{4}$ oxidation in the natural ecosystem, however, the pattern of MOB population and their activity are not well documented. Most studies in forest soils are, hence focused on the activity and diversity of methanotrophs. For tropical 
RESEARCH ARTICLES

Table 1. Physico-chemical characteristics of soils (mean \pm SE)

\begin{tabular}{|c|c|c|c|}
\hline \multirow[b]{2}{*}{ Characteristics } & \multicolumn{3}{|c|}{ Experimental sites } \\
\hline & Hilltop (Naugarh) & Middle (Jamsoti) & Hillbase (Chakia) \\
\hline Altitude (msl) (m) & 300 & 150 & 90 \\
\hline Bulk density $\left(\mathrm{g} \mathrm{cm}^{-3}\right)$ & $1.94 \pm 0.09$ & $1.90 \pm 0.04$ & $1.77 \pm 0.03$ \\
\hline Soil texture & Sand $25 \%$, silt $54.63 \%$, clay $20.37 \%$ & Sand $20 \%$, silt $54 \%$, clay $26 \%$ & Sand $16 \%$, silt $56 \%$, clay $28 \%$ \\
\hline $\mathrm{TN}\left(\mathrm{mg} \mathrm{kg}^{-1}\right)$ & $823.66 \pm 16.28$ & $1230 \pm 18.71$ & $1560 \pm 33.22$ \\
\hline TOC $\left(\mathrm{mg} \mathrm{kg}^{-1}\right)$ & $6220.66 \pm 158.33$ & $9803.33 \pm 278.35$ & $16311.67 \pm 115.97$ \\
\hline $\mathrm{pH}$ & $6.99-5.89$ & $6.76-5.21$ & $7.53-6.06$ \\
\hline $\mathrm{EC}\left(\mu \mathrm{S} \mathrm{m}{ }^{-1}\right)$ & $21.73 \pm 1.86$ & $57.25 \pm 2.58$ & $74.96 \pm 1.0$ \\
\hline
\end{tabular}

dry deciduous forest soils, the information on $\mathrm{MOB}$ population size seems equally important but has not been studied well.

Quantitative data in these lines can be used to relate potential changes in gene abundance and/or the level of gene expression associated with shifts in abiotic determinants ${ }^{27}$. Accordingly, systematic database on the magnitude of MOB population size may possibly add to furthering our understanding of the significance of $\mathrm{MOB}$ in the ecology of $\mathrm{CH}_{4}$ oxidation in forest soils. Few reports are available on the population size of methanotrophs in forest soils of temperate regions ${ }^{28,29}$. Giri et al. ${ }^{30}$ used most probable number (MPN) technique for counting MOB in tropical forest soils. This technique, however, has its own bias due to selective culture conditions. Overall, in tropical forest soils, information on MOB is almost scanty, particularly in the context of Indian tropical forests that constitute a major global share ${ }^{31}$.

Understanding the key determinants of activity and MOB population size here, has relevance because the dry deciduous tropical forest of Vindhyan region constitutes $\sim 53 \%$ of total forest area of India. This study was targeted to investigate the effect of topography, tree species and seasonal factors on MOP and MOB population size in the dry deciduous tropical forest soils of dry tropics.

\section{Materials and methods}

\section{Study site}

The experimental sites were located in the dry deciduous tropical forest of Vindhyan plateau situated in Chandauli district of eastern Uttar Pradesh, India. The climate of this region is tropical monsoonal, and receives about $82-$ $85 \%$ rainfall during rainy season (late June-September) due to southwest monsoon. The whole year is divisible into three seasons: rainy (late June-September), winter (October-February) and summer (March-early June). The annual mean rainfall ranges from 400 to $900 \mathrm{~mm}$, while mean monthly temperature varies between a minimum of $8^{\circ} \mathrm{C}$ in January to maximum $42^{\circ} \mathrm{C}$ in June. The average rainfall in rainy, winter and summer season during study period was $685.0,3.0$ and $2.0 \mathrm{~mm}$ respectively. The soil order of the study sites was Ultisols and red to brown in colour. The vegetation in the study area represents northern tropical mixed deciduous forest ${ }^{32}$, with the abundance of woody plants such as Butea monosperma, Boswellia serrata, Lagerstroemia parviflora, Tectona grandis, Madhuca indica, Acacia catechu, Ziziphus oenoplia, Ziziphus glaberrima, etc. The under storey vegetation of the forest floor mainly comprised of Lantana camara, Eragastris sp., Dicanthium sp., Desmostachya binnata, Oplismenus sp., Trifolium sp., Cassia tora, Phyllanthus urinaria, Sida acuta and Sida cordifolia.

\section{Experimental design and soil sampling}

Soil samples were collected from three forest sites of Naugarh, Jamsoti and Chakia, representing upper, middle and lower elevation landscapes at a height of $300 \mathrm{~m}$, $150 \mathrm{~m}$ and $90 \mathrm{~m}$ respectively (Table 1). At each site, three plots of 1 hectare (ha) area were randomly demarcated, based on the respective dominance of Butea monosperma, Tectona grandis and Madhuca indica. From each plot, soil samples were taken from $0-15 \mathrm{~cm}$ depth using a corer in triplicate at five randomly selected locations. Triplicates were mixed to form a composite sample $(n=15)$. Also, at each site, three plots, 1 ha each, were selected to represent off-canopy condition. Thus, a total of 30 composite soil samples (15 each for inside and outside canopy) were collected from each site in a month, and three times in a season (rainy: July, August, September; winter: November, December, January; summer: March, April, May), for two consecutive years (2016 and 2017). Soil sampling was avoided during February, June and October as they were identified as transition month of winter-summer, summer-rainy and rainy-winter seasons respectively. Soil samples were sieved ( $2 \mathrm{~mm}$ mesh) to remove fine roots, and were aliquoted into two: one part was stored at $-20^{\circ} \mathrm{C}$ for $\mathrm{qPCR}$ analyses and the other at $4^{\circ} \mathrm{C}$ for $\mathrm{CH}_{4}$ oxidation experiments and soil 
physico-chemical studies. All analyses were done in triplicate.

\section{Soil properties}

Soil variables such as $\mathrm{pH}$, texture, bulk density (BD) and water holding capacity (WHC) were determined using standard protocol described in Vishwakarma and Dubey $^{33}$. In brief, the soil particle proportions were estimated using sieves of variable mesh sizes and hydrometer method $^{34}$. The BD of the soil samples were determined by core method $^{35}$. The perforated circular brass boxes were used to determine WHC of the soil samples as described by $\operatorname{Piper}^{35}$. The soil : water $(1: 2.5 ; \mathrm{w} / \mathrm{v})$ suspensions were used to measure soil $\mathrm{pH}$ using $\mathrm{pH}$ meter equipped with a glass electrode (CyberScan pH 510, Eutec Instruments Pte Ltd). The electrical conductivity was measured in soil water suspension using digital conductivity meter (Systronics, India). Macrokjeldahl method was used for total soil $\mathrm{N}$ estimation ${ }^{36}$. For the measurements of organic carbon (C), dichromate oxidation procedure was followed $^{37}$. Leaf litter was collected during the peak litter fall period (February to March) of the year 2017. The litter samples were oven dried, and powdered to determine $\mathrm{C}$ and $\mathrm{N}$ content as per the standard protocol.

\section{Soil moisture and ammonium-N content}

Soil moisture was determined by gravimetric method. Exchangeable $\mathrm{NH}_{4}^{+}-\mathrm{N}$ was estimated in $2 \mathrm{M} \mathrm{KCl}$ extracts, and analysed spectrophotometrically by phenate $\operatorname{method}^{38}$.

\section{Methane oxidation potential}

Laboratory incubation experiment was used to determine $\mathrm{CH}_{4}$ oxidation in soils ${ }^{33}$. In brief, $10 \mathrm{~g}$ of soil sample was allowed to equilibrate for $24 \mathrm{~h}$ at $25^{\circ} \mathrm{C}$, and then, transferred to gastight $135-\mathrm{ml}$ Erlenmeyer flask, added with $50 \mu \mathrm{mol} \mathrm{l}^{-1}$ ( 1150 ppmv) $\mathrm{CH}_{4}$ (Sigma Aldrich; 99.9\% pure), and incubated for 10 days in dark at $30^{\circ} \mathrm{C}$. Further, for $\mathrm{CH}_{4}$ analysis, headspace samples $(100 \mu \mathrm{l})$ were withdrawn using a gas-tight glass syringe every $24 \mathrm{~h}$ up to $240 \mathrm{~h}$. The gas samples were analysed in Agilent 7820A gas chromatograph attached with a flame ionization detector (FID), Porapak N column, and nitrogen as the carrier gas (flow rate $12 \mathrm{ml} \mathrm{min}^{-1}$ ). The temperature for column, injector and detector was maintained as $180^{\circ} \mathrm{C}$, $210^{\circ} \mathrm{C}$ and $250^{\circ} \mathrm{C}$ respectively. MOP is expressed as nano gram $\mathrm{CH}_{4}$ per hour per gram of dry weight soil (dws).

\section{Population size of $M O B$}

Genomic DNA was extracted from the forest soil samples (0.5 g) using FastDNA Spin Kit for Soil (MP Bio- medicals, LLC, Solon, Ohio, USA) by a bead beater (FastDNAprep, MP Bio, USA) for lysis of cells according to a manufacturer's protocol. Real-time PCR was performed using iCycler iQ5 thermocycler (Bio-Rad). Population of methanotrophs was quantified using specific primer pair A189f 5'GGNGACTGGGACTTCTGG3' and mb661r 5'CCGGMGCAACGTCYTTACC3' (refs 39, 40). The reaction mixture $(20 \mu \mathrm{l})$ contained $10 \mu \mathrm{l}$ of PowerUp ${ }^{\text {TM }}$ SYBR ${ }^{\text {TM }}$ Green Master Mix (Applied Biosystem), $0.4 \mu \mathrm{l}$ of each primer $(10 \mu \mathrm{M}), 2 \mu \mathrm{l}$ DNA template $(50 \mathrm{ng} / \mu \mathrm{l})$ and DNAase/RNase-free water to the final volume of $20 \mu \mathrm{l}$. For each sample, the reactions were performed in duplicate and for plasmid standards, samples were analysed in triplicate. PCR conditions for methanotrophs were optimized as three step cycling protocol with the initial $4 \mathrm{~min}$ denaturation $\left(94^{\circ} \mathrm{C}\right)$, followed by 40 cycles of denaturation $\left(94^{\circ} \mathrm{C}\right.$ for $\left.15 \mathrm{~s}\right)$, annealing at $56^{\circ} \mathrm{C}$ for $30 \mathrm{~s}$ and extension at $60^{\circ} \mathrm{C}$ for $30 \mathrm{~s}$. Fluorescence data were acquired at $77.5^{\circ} \mathrm{C}$ after each consecutive cycle. After completion of 40 cycles, the melting curve analyses were performed by increasing the temperature from $60^{\circ} \mathrm{C}$ to $95^{\circ} \mathrm{C}$ and recording fluorescence for every $0.5^{\circ} \mathrm{C}$ increase. Plasmid DNA containing the target gene (methanotrophic bacteria specific pmoA gene) was taken as the standard DNA in PCR (real time) assay acquired by PCR-cloning using A189f and mb661r primer pairs. Plasmids were isolated using HiPurA (TM) Plasmid DNA Miniprep Purification Kit (Himedia), and DNA concentration was determined by Nanodrop 2000 spectrophotometer (Thermoscientific). Standard curves were prepared with triplicate 10 -fold dilutions of plasmid DNA ${ }^{29}$.

Data were tested for PCR efficiency. The values for methanotrophs (slope: -3.729; $R^{2}$ : 0.983; efficiency: $85.4 \%$ ) were within the suggested range. Zhang and Fang $^{41}$ mentioned that in practice, for an appropriate standard curve, $R^{2}$ should be above 0.95 , with slope from -3.0 to -3.9 corresponding to PCR efficiency of 80 $115 \%$

\section{Statistical analysis}

For statistical treatments, data were subjected to multivariate analysis of variance (MANOVA) to record significant effect of year, topography, season and tree species on the observed variables. Simple Pearson's correlation coefficient analysis was applied to determine the relationship of parameters to each other. The statistical analyses were performed using IBM SPSS version 20.0 (ref. 42).

\section{Results}

\section{Soil properties and leaf litter $C$ and $N$}

Results on soil characteristics are presented in Table 1. Soil texture consisted predominately of silty type at higher 
Table 2. Variations in soil moisture (\%) and $\mathrm{NH}_{4}^{+}-\mathrm{N}$ content ( $\mu \mathrm{g} \mathrm{g}^{-1}$ dry weight soil) at hilltop (Naugarh), Middle (Jamsoti) and hillbase (Chakia) under the canopy of B. monosperma, T. grandis, M. indica and outer canopy during rainy, winter and summer season for two consecutive years (2016 and 2017) (mean \pm SE)

\begin{tabular}{|c|c|c|c|c|c|c|c|c|c|}
\hline \multirow{2}{*}{ Site } & \multirow{2}{*}{ Season } & \multicolumn{8}{|c|}{ Tree species } \\
\hline & & \multicolumn{2}{|c|}{ B. monosperma } & \multicolumn{2}{|c|}{ T. grandis } & \multicolumn{2}{|c|}{ M. indica } & \multicolumn{2}{|c|}{ Outer canopy } \\
\hline \multicolumn{10}{|l|}{2016} \\
\hline \multirow[t]{3}{*}{ Hilltop (Naugarh) } & Rainy & $16.7 \pm 0.75$ & $0.19 \pm 0.03$ & $18.6 \pm 1.39$ & $0.16 \pm 0.02$ & $15.8 \pm 2.02$ & $0.17 \pm 0.04$ & $12.2 \pm 0.57$ & $0.12 \pm 0.02$ \\
\hline & Winter & $5.1 \pm 0.54$ & $0.67 \pm 0.01$ & $8.7 \pm 0.67$ & $0.72 \pm 0.01$ & $7.9 \pm 0.16$ & $0.73 \pm 0.02$ & $6.0 \pm 0.54$ & $0.54 \pm 0.00$ \\
\hline & Summer & $4.3 \pm 0.36$ & $0.75 \pm 0.01$ & $6.3 \pm 0.35$ & $0.73 \pm 0.04$ & $5.1 \pm 0.48$ & $0.79 \pm 0.02$ & $3.6 \pm 0.37$ & $0.64 \pm 0.02$ \\
\hline \multirow[t]{3}{*}{ Middle (Jamsoti) } & Rainy & $17.4 \pm 0.29$ & $0.20 \pm 0.02$ & $19.7 \pm 1.84$ & $0.27 \pm 0.02$ & $17.5 \pm 0.86$ & $0.24 \pm 0.05$ & $14.8 \pm 0.16$ & $0.16 \pm 0.02$ \\
\hline & Winter & $6.9 \pm 0.26$ & $0.67 \pm 0.05$ & $8.6 \pm 0.28$ & $0.71 \pm 0.04$ & $7.4 \pm 0.17$ & $0.63 \pm 0.02$ & $6.4 \pm 0.65$ & $0.57 \pm 0.01$ \\
\hline & Summer & $4.9 \pm 0.41$ & $0.72 \pm 0.04$ & $7.9 \pm 0.53$ & $0.73 \pm 0.05$ & $5.4 \pm 0.51$ & $0.77 \pm 0.02$ & $3.9 \pm 0.16$ & $0.58 \pm 0.00$ \\
\hline \multirow[t]{3}{*}{ Hillbase (Chakia) } & Rainy & $17.0 \pm 0.12$ & $0.76 \pm 0.09$ & $22.4 \pm 0.97$ & $0.73 \pm 0.02$ & $19.8 \pm 0.33$ & $0.49 \pm 0.04$ & $13.3 \pm 0.48$ & $0.43 \pm 0.02$ \\
\hline & Winter & $7.6 \pm 0.55$ & $0.78 \pm 0.02$ & $9.5 \pm 0.36$ & $0.73 \pm 0.08$ & $8.8 \pm 0.13$ & $0.86 \pm 0.01$ & $6.0 \pm 0.44$ & $0.78 \pm 0.03$ \\
\hline & Summer & $5.8 \pm 0.32$ & $0.77 \pm 0.01$ & $9.4 \pm 0.23$ & $1.05 \pm 0.09$ & $6.5 \pm 0.29$ & $0.80 \pm 0.03$ & $5.1 \pm 0.43$ & $0.76 \pm 0.02$ \\
\hline \multicolumn{10}{|l|}{2017} \\
\hline \multirow{2}{*}{ Hilltop (Naugarh) } & Winter & $5.5 \pm 0.25$ & $0.62 \pm 0.01$ & $7.2 \pm 0.28$ & $0.65 \pm 0.02$ & $5.6 \pm 0.41$ & $0.63 \pm 0.02$ & $4.6 \pm 0.22$ & $0.46 \pm 0.01$ \\
\hline & Summer & $4.4 \pm 0.39$ & $0.68 \pm 0.01$ & $6.0 \pm 0.39$ & $0.71 \pm 0.03$ & $5.5 \pm 0.45$ & $0.74 \pm 0.02$ & $3.6 \pm 0.69$ & $0.55 \pm 0.01$ \\
\hline \multirow[t]{3}{*}{ Middle (Jamsoti) } & Rainy & $17.9 \pm 0.30$ & $0.17 \pm 0.02$ & $21.0 \pm 0.25$ & $0.18 \pm 0.03$ & $21.0 \pm 0.25$ & $0.22 \pm 0.05$ & $14.6 \pm 0.42$ & $0.14 \pm 0.02$ \\
\hline & Winter & $6.3 \pm 0.22$ & $0.69 \pm 0.04$ & $8.4 \pm 0.78$ & $0.65 \pm 0.03$ & $8.7 \pm 0.78$ & $0.59 \pm 0.02$ & $3.7 \pm 0.19$ & $0.52 \pm 0.02$ \\
\hline & Summer & $5.6 \pm 0.15$ & $0.75 \pm 0.04$ & $6.1 \pm 0.24$ & $0.72 \pm 0.04$ & $6.1 \pm 0.24$ & $0.74 \pm 0.02$ & $3.8 \pm 0.58$ & $0.55 \pm 0.01$ \\
\hline \multirow[t]{3}{*}{ Hillbase (Chakia) } & Rainy & $17.0 \pm 0.18$ & $0.74 \pm 0.04$ & $18.2 \pm 0.15$ & $0.68 \pm 0.02$ & $15.4 \pm 0.35$ & $0.61 \pm 0.03$ & $14.5 \pm 0.41$ & $0.62 \pm 0.01$ \\
\hline & Winter & $9.1 \pm 0.10$ & $0.89 \pm 0.00$ & $9.8 \pm 0.29$ & $1.01 \pm 0.01$ & $7.8 \pm 0.76$ & $0.92 \pm 0.04$ & $5.9 \pm 0.42$ & $0.92 \pm 0.02$ \\
\hline & Summer & $6.0 \pm 0.10$ & $0.94 \pm 0.01$ & $6.6 \pm 0.11$ & $0.98 \pm 0.02$ & $5.8 \pm 0.33$ & $1.02 \pm 0.07$ & $4.9 \pm 0.24$ & $0.86 \pm 0.01$ \\
\hline
\end{tabular}

topography (Naugarh and Jamsoti), while silty clay loam type at hillbase (Chakia). Bulk density varied from 1.77 to $1.94 \mathrm{~g} \mathrm{~cm}^{-3}$. The bulk density was highest at hilltop followed by middle and hillbase. The soil $\mathrm{pH}$ ranged from 5.21 to 7.53 . The water holding capacity was maximum for hillbase followed by middle and hilltop. Total organic $\mathrm{N}$ and $\mathrm{C}$ ranged from 823.6 to 1536 and 6220.7 to $16311.0 \mathrm{mg} \mathrm{kg}^{-1}$ respectively, with highest value at hillbase followed by middle and hilltop. The EC value ranged from 21.7 to $74.96 \mu \mathrm{S} \mathrm{m}^{-1}$ along the topography. In leaf litter samples, $\mathrm{C}$ content was maximum (467.5 $\mathrm{mg} \mathrm{g}^{-1}$ ) in $T$. grandis followed by $M$. indica $\left(433.07 \mathrm{mg} \mathrm{g}^{-1}\right.$ ) and B. monosperma (413.07 $\mathrm{mg} \mathrm{g}^{-1}$ ). The $\mathrm{N}$ content also followed the similar trend as $\mathrm{C}$ with the value $20.1,10.3$ and $5.1 \mathrm{mg} \mathrm{g}^{-1}$ for $T$. grandis, $M$. indica and $B$. monosperma respectively.

\section{Soil moisture and ammonium-N content}

Soil moisture and $\mathrm{NH}_{4}^{+}-\mathrm{N}$ content at each site during the study period (2016 and 2017) have been shown in Table 2. Soil moisture was significantly higher during rainy season, and it ranged from $11.9 \%$ to $22.4 \%, 3.7 \%$ to $9.8 \%$ and $3.6 \%$ to $9.4 \%$ during rainy, winter and summer season respectively, at all the sites throughout study period. Multivariate analysis of variance (MANOVA) indicated significant effect of year $\left(\mathrm{F}_{1,214}=33.51 ; p<0.001\right)$, topography $\left(\mathrm{F}_{2,213}=33.51 ; p<0.001\right)$, season $\left(\mathrm{F}_{2,213}=\right.$
4091.04; $p<0.001)$ and tree species $\left(\mathrm{F}_{3,212}=223.80\right.$; $p<0.001)$ on the soil moisture content.

At all the sites, soil $\mathrm{NH}_{4}^{+}-\mathrm{N}$ content varied from 0.07 to $0.76,0.46$ to 1.01 and 0.55 to $1.05 \mu \mathrm{g} \mathrm{g}^{-1} \mathrm{dws}$ during rainy, winter and summer season respectively. The $\mathrm{NH}_{4}^{+}-$ $\mathrm{N}$ content of the soil showed pattern reverse to that of soil moisture being maximum during summer, followed by winter and rainy season at each study site. The significant effect of the topography $\left(\mathrm{F}_{1,214}=900.88 ; p<0.001\right)$, season $\left(\mathrm{F}_{2,213}=1864.24 ; p<0.001\right)$, tree species $\left(\mathrm{F}_{3,212}=\right.$ $82.34 ; p<0.001)$, except year $\left(\mathrm{F}_{1,214}=0.76 ; p>0.001\right)$ was observed on the soil $\mathrm{NH}_{4}^{+}-\mathrm{N}$ content.

\section{Methane oxidation potential}

Methane oxidation potential of soils varied from 12.2 to 21.5, 9.9 to 21.0 and 11.20 to $20.8 \mathrm{ng} \mathrm{CH}_{4} \mathrm{~g}^{-1} \mathrm{~h}^{-1} \mathrm{dws}$ at Hilltop (Naugarh), Middle (Jamsoti) and Hillbase (Chakia) forest site respectively (Figure 1). The MANOVA demonstrated topography $\left(\mathrm{F}_{2,213}=74.12 ; p<0.001\right)$, season $\left(\mathrm{F}_{2,213}=1703.68 ; p<0.001\right)$ and tree species $\left(\mathrm{F}_{3,212}=\right.$ $102.34 ; p<0.001)$ were significant determinants of soil MOP. MOP varied along the topography being maximum at hilltop followed by middle and hillbase. Significant $(p<0.001)$ seasonal variability, with high $\mathrm{CH}_{4}$ oxidation rates during dry periods (winter and summer) compared to wet season, was recorded. Tree species had significant $(p<0.001)$ effect on $\mathrm{CH}_{4}$ oxidation with the maximum 


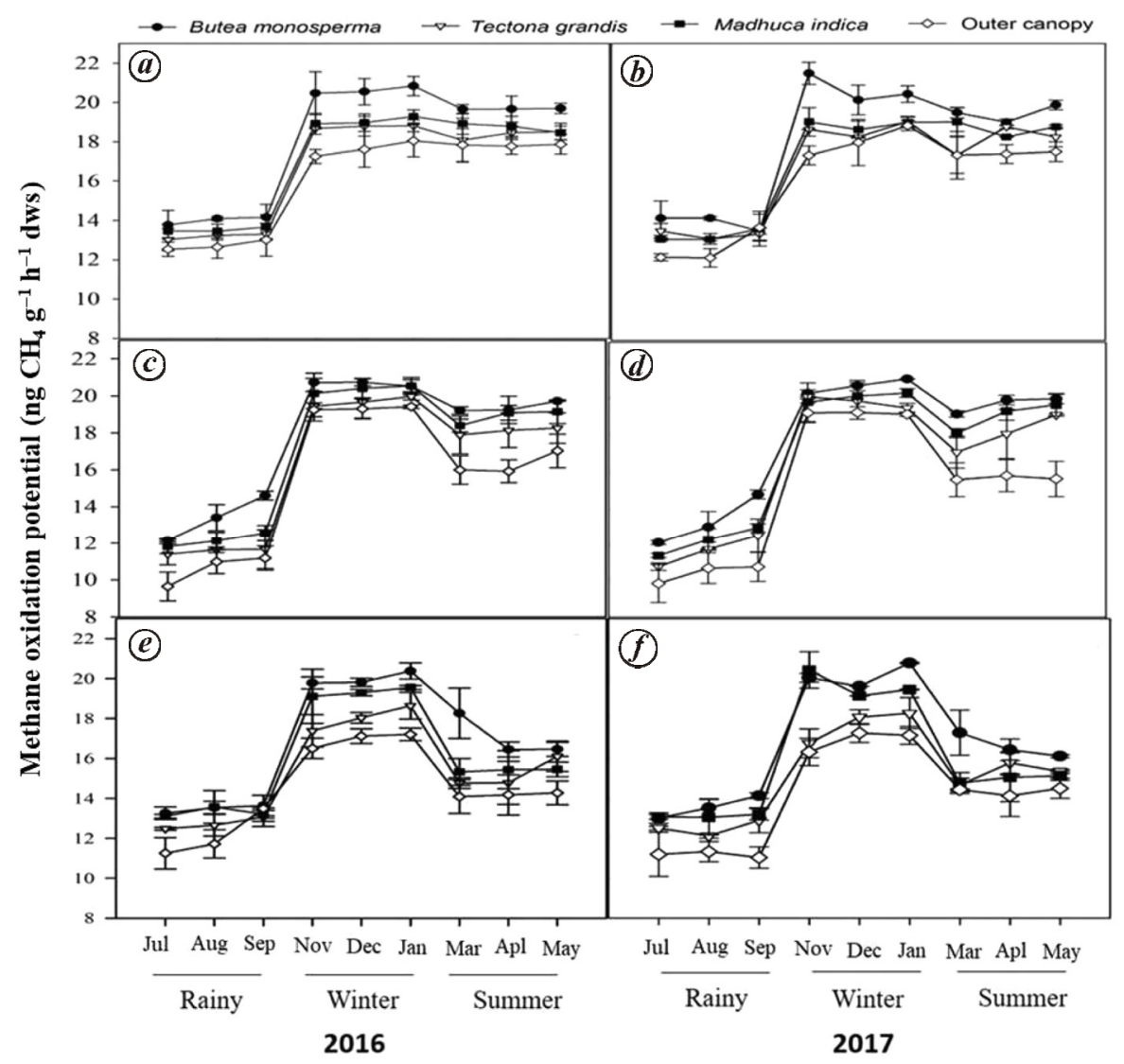

Figure 1. Variation in the $\mathrm{CH}_{4}$ oxidation potential at hilltop (Naugarh) ( $\boldsymbol{a}$ and $\boldsymbol{b}$ ), middle (Jamsoti) ( $\boldsymbol{c}$ and $\left.\boldsymbol{d}\right)$ and hillbase (Chakia) ( $\boldsymbol{e}$ and $\boldsymbol{f}$ ) forest site respectively, during 2016 and 2017.

for Butea monosperma followed by Madhuca indica, Tectona grandis, and the outer canopy.

\section{Quantification of $M O B$ population}

Variations in methanotrophic population size along the topography, in different seasons, and tree species for the year 2016 and 2017 are depicted in Figure 2. The population size of methanotrophs as estimated by the pmo $A$ gene copy number varied between $7.0 \times 10^{5}$ and $3.0 \times$ $10^{7}$ copies $\mathrm{g}^{-1} \mathrm{dws}$. The MANOVA showed significant effect of topography $\left(\mathrm{F}_{2,213}=63.58 ; p<0.001\right)$, season $\left(\mathrm{F}_{2,213}=584.52 ; p<0.001\right)$ and tree species $\left(\mathrm{F}_{3,212}=41.5\right.$; $p<0.001)$ on the population size of methanotrophs. The population size was smallest in soil samples from the outer canopy. The methanotrophic population size was maximum in soils from the under canopy of Butea monosperma, followed by Madhuca indica and Tectona grandis irrespective of the topography and season.

\section{Discussion}

\section{Effect of topography}

Methane oxidation range recorded here (9.9 to $21.5 \mathrm{ng}$ $\mathrm{CH}_{4} \mathrm{~g}^{-1} \mathrm{~h}^{-1} \mathrm{dws}$ ), is comparable with those observed for soil of the temperate forest in Massachusetts ${ }^{43}$, hardwood forest of South $\mathrm{Korea}^{44}$, and the deciduous forest of Europe $^{29}$. Topographical gradient showed significant $(p<0.001)$ effect on $\mathrm{CH}_{4}$ oxidation being highest at hilltop followed by middle and hillbase site. Such a difference in $\mathrm{CH}_{4}$ oxidation values could be correlated with high population size of methanotrophs at higher topography followed by middle and hillbase (Figure 2). So far, MOB population in terms of gene copy number is not available for data comparison from other regional scale studies. The data presented here, which form the first report from Indian tropics, can be used for comparing the values reported from other ecozones/ecosystems using comparable methodologies. Barcena et $a l^{28}$ reported MOB population between $10^{6}$ and $10^{7}$ copies $\mathrm{g}^{-1} \mathrm{dws}$ in oak dominated temperate forest of Denmark. Malghani et $a l .{ }^{29}$ recorded methanotrophic population ranging from $4.3 \times 10^{7}$ to $7.5 \times 10^{7}$ copies $\mathrm{g}^{-1} \mathrm{dws}$ in a temperate deciduous beech forest of Germany. We found strong correlation $(r=0.89 ; p<0.01)$ between $\mathrm{CH}_{4}$ oxidation and methanotrophic population irrespective of the topographic variation. Further, the hilltop site showed significant negative correlation $(r=-0.76 ; p<0.01)$ between MOP and the soil moisture content. The results of regression analysis of $\mathrm{CH}_{4}$ oxidation and methanotrophic population to the soil physicochemical variables (BD, clay content, 


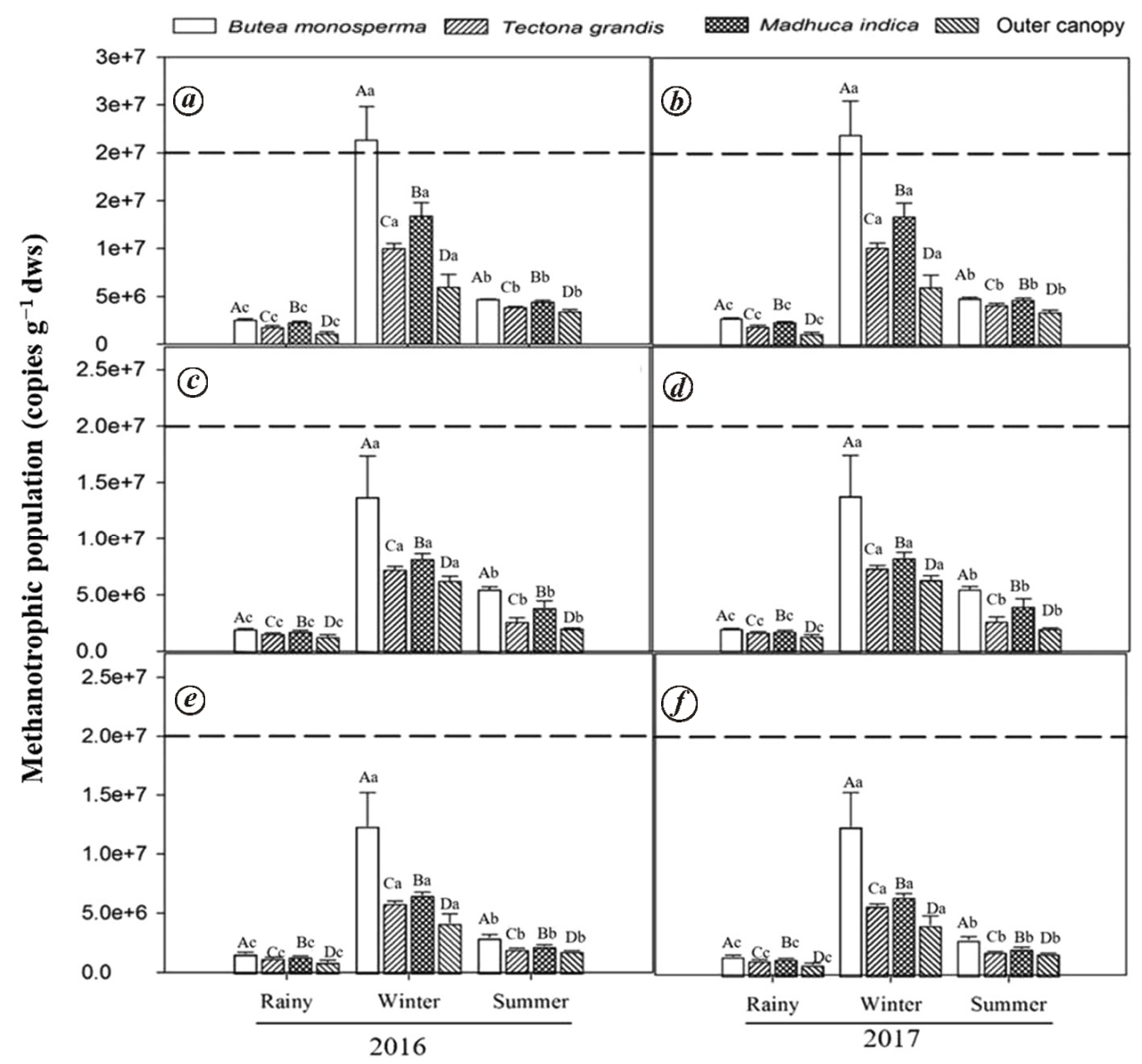

Figure 2. Population size of methanotrophs at hilltop (Naugarh) ( $\boldsymbol{a}$ and $\boldsymbol{b}$ ), middle (Jamsoti) (c and $\boldsymbol{d})$, and hillbase (Chakia) ( $\boldsymbol{e}$ and $\boldsymbol{f}$ ) study site for two consecutive years. Different uppercases denote significant differences (at $p<0.01$ ) between tree species in the same season and different lowercases denotes significant differences between seasons in the same tree species according to the Tukey's HSD test.

WHC, total organic carbon, total nitrogen and electric conductivity) are presented in Table 3 . The clay content of the soil was found to be negatively correlated with the $\mathrm{CH}_{4}$ oxidation and MOB population size $\left(R^{2}=0.98\right.$; $p<0.001)$. The hilltop site with high coarse particles showed higher $\mathrm{CH}_{4}$ oxidation compared to hillbase rich in clay content. This result is similar to that of Boeckx et $a l .{ }^{45}$ who reported higher $\mathrm{CH}_{4}$ uptake rate in coarse soil compared to fine textured soils of Belgium forests. Fine particles of the soil regulate $\mathrm{CH}_{4}$ uptake by regulating the diffusion of atmospheric $\mathrm{CH}_{4}$ and oxygen in the soil ${ }^{46}$. In general, the site situated at the lower elevation, receives high erosional residues rich in soil organic matter, soluble salts, mineral colloids, etc. subject to natural downhill movement assisted by runoff. Subject to limited $\mathrm{O}_{2}$ supply, the accumulation of organic substances creates anaerobic microhabitats and consequently limits methanotrophy ${ }^{47}$. The soil organic carbon and nitrogen were found to be negatively correlated with $\mathrm{CH}_{4}$ oxidation and population size (Table 3 ). The overall results show that topographical variations with characteristically different soil properties are important determinants of population size of $\mathrm{CH}_{4}$ oxidizers, and consequently the MOP of the soil.

\section{Effect of tree species}

MOP and MOB population size, both varied significantly with tree species. The soil samples from the under canopy of Butea monosperma showed maximum $\mathrm{CH}_{4}$ oxidation rate followed by those cultivated with Madhuca indica, Tectona grandis and outer canopies. The outer canopy soil with poor organic input was poor in $\mathrm{CH}_{4}$ oxidation. The methanotrophic population at each outer canopy site, during every season was also poor. In a previous study, Reay et $a l .{ }^{23}$ reported the effect of vegetation type (alder, oak, Norway spruce, Scots pine and grassland) on high and low affinity MOP in Bowland forest, UK. They reported large reduction in $\mathrm{CH}_{4}$ oxidation in alder soils than those from other vegetation types, and linked the process with the inhibitory effects of high nitrate concentrations. Tree species influence nitrogen capture and mineralization ${ }^{48}$. The litter composition strongly 
Table 3. Result of regression analysis $(Y=a \pm b X)$ of $\mathrm{CH}_{4}$ oxidation potential (MOP) (ng $\mathrm{CH}_{4} \mathrm{~g}^{-1} \mathrm{~h}^{-1} \mathrm{dws}$ ) and methanotrophic population size $\left(Y, \times 10^{6}\right.$ copies $\left.\mathrm{g}^{-1} \mathrm{dws}\right)$ to different variables (bulk density, clay content, EC, WHC, total organic carbon, total nitrogen)

\begin{tabular}{|c|c|c|c|c|c|}
\hline$Y$ & $X$ & $a$ & $b$ & $R^{2}$ & Significance level \\
\hline MOP & Bulk density & 1.66 & 0.01 & 0.17 & NS \\
\hline MOP & Clay & 41.07 & -0.90 & 0.98 & $* * *$ \\
\hline MOP & $\mathrm{EC}$ & 133.33 & -4.52 & 0.59 & $*$ \\
\hline MOP & WHC & 46.17 & -0.17 & 0.09 & NS \\
\hline MOP & Total organic carbon & 29665.68 & -1039.10 & 0.88 & $* * *$ \\
\hline MOP & Total nitrogen & 2589.35 & -76.63 & 0.97 & $* * *$ \\
\hline Methanotrophic population & Clay & 32.47 & -1.61 & 0.94 & $*$ \\
\hline Methanotrophic population & $\mathrm{EC}$ & 86.31 & -7.35 & 0.46 & $* * *$ \\
\hline Methanotrophic population & WHC & 45.15 & -0.43 & 0.18 & NS \\
\hline Methanotrophic population & Total organic carbon & 20180.80 & -1971.20 & 0.95 & $* * *$ \\
\hline Methanotrophic population & Total nitrogen & 1868.57 & -140.88 & 0.98 & $* * *$ \\
\hline
\end{tabular}

MOP; Methane oxidation potential; NS, Not significant; ${ }^{*} p<0.05,{ }^{*} p<0.01,{ }^{* * *} p<0.001$.

Table 4. Pearson correlation coefficient of parameter studied during two consecutive years at all the sites studied

\begin{tabular}{lcccc}
\hline Parameters & Moisture & Ammonium-N & MOP & $\begin{array}{c}\text { pmoA gene } \\
\text { copy no. }\end{array}$ \\
\hline Moisture & 1 & & & \\
Ammonium-N & $-0.61^{*}$ & 1 & & \\
MOP & $-0.76^{*}$ & $0.32^{*}$ & 1 & \\
pmoA gene copy no. & $-0.41^{*}$ & $0.28^{*}$ & $0.90^{*}$ & 1 \\
\hline
\end{tabular}

*Significant at $p<0.01 ; n=216$.

influences microbial colonization. The organic $\mathrm{C}$ and $\mathrm{N}$ content of the leaf litter of the tree species considered in this study showed significant variations. Fresh leaf litter of Tectona grandis, rich in organic $\mathrm{C}$ and $\mathrm{N}$, might release $\mathrm{N}$ to the soil in proportion high enough to interfere with $\mathrm{CH}_{4}$ oxidation through regulation of methanotrophic activity. Soil moisture also varied significantly $(p<0.05)$ with tree species, being highest for the under canopy soil of $T$. grandis followed by $M$. indica and $B$. monosperma (Table 2). The $\mathrm{CH}_{4}$ oxidation rate and MOB population size were negatively correlated with the soil moisture (Table 4). Therefore, variation in soil moisture content could lead to changes in $\mathrm{CH}_{4}$ oxidation across under canopy soils of different plant.

\section{Effect of season}

The MANOVA revealed significant $(p<0.001)$ seasonal variation in $\mathrm{CH}_{4}$ oxidation. Seasonal variations in $\mathrm{CH}_{4}$ oxidation were well linked with soil moisture. During rainy season, with maximum soil moisture, $\mathrm{CH}_{4}$ oxidation declined sharply (Figure 1). Previous reports also indicated decrease in $\mathrm{CH}_{4}$ oxidation rates ${ }^{21}$ with increasing soil moisture. The population size of methanotrophs was high during winter, followed by summer and rainy season (Figure 2). In summer, the moisture content of the soil goes below 5\%, which adversely affects the microbial population. Although soil moisture content is negatively correlated with $\mathrm{CH}_{4}$ oxidation, it may show positive correlation below 8\% (ref. 49). Ammonium-N was maximum in summer, followed by winter and rainy (Table 2). High ammonium-N content in the soil might be attributed to low nitrification during summer. In rainy season, high demand for nutrients by the growing vegetation leads to decline in $\mathrm{NH}_{4}^{+}-\mathrm{N}$ (ref. 50). While in most cases, $\mathrm{CH}_{4}$ oxidation of in forest soils is inhibited by $\mathrm{N}$ additions ${ }^{51,52}$, $\mathrm{NH}_{4}^{+}-\mathrm{N}$ in our study, showed significant but poor positive correlation with $\mathrm{CH}_{4}$ oxidation (Table 3). Methane oxidation is inhibited in case inorganic $\mathrm{N}$ was substantially high. Positive effects of $\mathrm{N}$ on $\mathrm{CH}_{4}$ oxidation have been reported in rice field ${ }^{53}$ and forest soils ${ }^{54}$.

\section{Inter-annual variation}

The $\mathrm{CH}_{4}$ oxidation and methanotrophic population did not show significant annual variation although, for soil moisture it was significant. The inter-annual variation in soil moisture might be due to relatively poor rainfall during 2017. Although methanotrophic population showed negative relationship with the soil moisture, no significant changes were recorded annually.

\section{Conclusions}

The estimates of MOP of dry tropical forest soils provide a reference for comparing other ecosystems in terms of process and the associated microbial communities. Our analyses document the extent of variation in MOP and MOB population distribution in relation to ecosystem variables linked with topography, tree species and seasonality. The soils of all the forest sites showed $\mathrm{CH}_{4}$ oxidizing potential, although it varied significantly with the topography, season and tree species. The soil MOP showed strong positive correlation with the MOB population size. Soil moisture emerged as the important driver 
regulating $\mathrm{CH}_{4}$ oxidation largely by regulating the diffusion of $\mathrm{CH}_{4}$ and $\mathrm{O}_{2}$. The study unravels the drivers of $\mathrm{CH}_{4}$ cycle in the seasonally dry tropical forest, and will certainly help in exploring regional contributors to global $\mathrm{CH}_{4}$ cycle. The study merits adding new dimensions furthering the need for assessment of molecular diversity of MOB, establishing the causal linkages, and enhancing sink efficiency of forest soils.

Conflict of interest: Authors have no any conflict of interest for this publication

1. Ciais, P. et al., Carbon and other biogeochemical cycles. In Climate Change 2013: The Physical Science Basis. Contribution of Working Group I to the Fifth Assessment Report of the Intergovernmental Panel on Climate Change (eds Stocker, T. F. et al.), Cambridge University Press, Cambridge, United Kingdom and New York, NY, USA, 2013, pp. 465-570

2. IPCC, Climate Change 2013: The Physical Science Basis. Contribution of Working Group I to the Fifth Assessment Report of the Intergovernmental Panel on Climate Change, Cambridge University Press, Cambridge, United Kingdom and New York, NY, USA, 2013, 1535.

3. Saunois, M. et al., The global methane budget 2000-2012. Earth Syst. Sci. Data, 2016, 8(2), 697-751.

4. Murguia-Flores, F., Arndt, S., Ganesan, A. L., Murray-Tortarolo, G. and Hornibrook, E. R. C., Soil Methanotrophy Model (MeMo $\mathrm{v} 1.0)$ : a process-based model to quantify global uptake of atmospheric methane by soil. Geosci. Model Dev., 2018, 11(6), 20092032.

5. Dutaur, L. and Verchot, L. V., A global inventory of the soil $\mathrm{CH}_{4}$ sink. Global Biogeochem. Cy., 2007, 21(4), 1-9.

6. Hanson, R. S. and Hanson, T. E., Methanotrophic bacteria. Microbiol. Rev., 1996, 60(2), 439-471.

7. Dubey, S. K., Microbial ecology of methane emission in rice agroecosystem: a review. Appl. Ecol. Environ. Res., 2005, 3(2), 127.

8. Guckland, A., Flessa, H. and Prenzel, J., Controls of temporal and spatial variability of methane uptake in soils of a temperate deciduous forest with different abundance of European beech (Fagus sylvatica L.). Soil Biol. Biochem., 2009, 41(8), 1659-1667.

9. Ishizuka, S., Sakata, T. and Ishizuka, K., Methane oxidation in Japanese forest soils. Soil Biol. Biochem., 2000, 32(6), 769-777.

10. Jang, I., Lee, S., Zoh, K. D. and Kang, H., Methane concentrations and methanotrophic community structure influence the response of soil methane oxidation to nitrogen content in a temperate forest. Soil Biol. Biochem., 2011, 43(3), 620-627.

11. Ueyama, M. et al., Methane uptake in a temperate forest soil using continuous closed-chamber measurements. Agr. Forest Meteorol., 2015, 213, 1-9.

12. Singh, J. S. et al., Effect of soil nitrogen, carbon and moisture on methane uptake by dry tropical forest soils. Plant Soil, 1997, 196(1), 115-121.

13. Yan, Y. P. et al., Fluxes of $\mathrm{CH}_{4}$ and $\mathrm{N}_{2} \mathrm{O}$ from soil under a tropical seasonal rain forest in Xishuangbanna, Southwest China. J. Environ. Sci. China, 2008, 20(2), 207-215.

14. Yu, L. J., Huang, Y., Zhang, W., Li, T. T. and Sun, W. J., Methane uptake in global forest and grassland soils from 1981 to 2010. Sci. Total Environ., 2017, 607, 1163-1172.

15. Dubey, S. K., Sinha, A. S. K. and Singh, J. S., Differential inhibition of $\mathrm{CH}_{4}$ oxidation in bare, bulk and rhizosphere soils of dryland rice field by nitrogen fertilizers. Basic Appl. Ecol., 2002, 3(4), 347-355.
16. Steudler, P. A., Bowden, R. D., Melillo, J. M. and Aber, J. D., Influence of nitrogen-fertilization on methane uptake in temperate forest soils. Nature, 1989, 341(6240), 314-316.

17. Tate, K. R. et al., Methane uptake in soils from Pinus radiata plantations, a reverting shrubland and adjacent pastures: effects of land-use change, and soil texture, water and mineral nitrogen. Soil Biol. Biochem., 2007, 39(7), 1437-1449.

18. Luo, G. J., Kiese, R., Wolf, B. and Butterbach-Bahl, K., Effects of soil temperature and moisture on methane uptake and nitrous oxide emissions across three different ecosystem types. Biogeosciences, 2013, 10(5), 3205-3219.

19. Benstead, J. and King, G. M., The effect of soil acidification on atmospheric methane uptake by a Maine forest soil. FEMS Microbiol. Ecol., 2001, 34(3), 207-212.

20. Zhang, J. F., Li, Z. J., Ning, T. Y. and Gu, S. B., Methane uptake in salt-affected soils shows low sensitivity to salt addition. Soil Biol. Biochem., 2011, 43(7), 1434-1439.

21. Shrestha, P. M., Kammann, C., Lenhart, K., Dam, B. and Liesack, W., Linking activity, composition and seasonal dynamics of atmospheric methane oxidizers in a meadow soil. ISME J., 2012, 6(6), 1115-1126.

22. Wolf, K., Flessa, H. and Veldkamp, E., Atmospheric methane uptake by tropical montane forest soils and the contribution of organic layers. Biogeochemistry, 2012, 111, 469-483.

23. Reay, D. S., Nedwell, D. B., McNamara, N. and Ineson, P., Effect of tree species on methane and ammonium oxidation capacity in forest soils. Soil Biol. Biochem., 2005, 37(4), 719-730.

24. Ishizuka, S. et al., Methane uptake rates in Japanese forest soils depend on the oxidation ability of topsoil, with a new estimate for global methane uptake in temperate forest. Biogeochemistry, 2009, 92, 281-295.

25. Mohanty, S. R., Bodelier, P. L. and Conrad, R., Effect of temperature on composition of the methanotrophic community in rice field and forest soil. FEMS Microbiol. Ecol., 2007, 62(1), 24-31.

26. Kravchenko, I. K. et al., Physicochemical and biological factors affecting atmospheric methane oxidation in gray forest soils. Microbiology, 2005, 74(2), 216-220.

27. Smith, C. J. and Osborn, A. M., Advantages and limitations of quantitative PCR (Q-PCR)-based approaches in microbial ecology. FEMS Microbiol. Ecol., 2009, 67(1), 6-20.

28. Barcena, T. G. et al., Conversion of cropland to forest increases soil $\mathrm{CH}_{4}$ oxidation and abundance of $\mathrm{CH}_{4}$ oxidizing bacteria with stand age. Appl. Soil Ecol., 2014, 79, 49-58.

29. Malghani, S. et al., Soil methanotroph abundance and community composition are not influenced by substrate availability in laboratory incubations. Soil Biol. Biochem., 2016, 101, 184-194.

30. Giri, D. D. et al., Variation in methanotrophic bacterial population along an altitude gradient at two slopes in tropical dry deciduous forest. Soil Biol. Biochem., 2007, 39(9), 2424-2426.

31. Keenan, R. J. et al., Dynamics of global forest area: results from the fao global forest resources assessment. Forest Ecol. Manage., 2015, 352, 9-20.

32. Champion, H. G. and Seth, S. K., A Revised Survey of the Forest Types of India, 1968; https://dds.crl.edu/crldelivery/23005.

33. Vishwakarma, P. and Dubey, S. K., The effect of soil type and plant age on the population size of rhizospheric methanotrophs and their activities in tropical rice soils. J. Basic Microbiol., 2007, 47(4), 351-357.

34. Bouyoucos, G. J., Hydrometer method improved for making particle size analyses of soils. Agron. J., 1962, 54(5), 464-465.

35. Piper, C. S., Soil and Plant Analysis, Inter Science Publication, Inc., Adelaide, Australia, 1944.

36. Jackson, M. L., Soil Chemical Analysis, Prentice Hall, New Jersey, USA, 1958.

37. Walkley, A., A critical examination of a rapid method for determining organic carbon in soils-effect of variations in digestion 
conditions and of inorganic soil constituents. Soil Sci., 1947, 63(4), 251-264.

38. APHA, Standard methods for the examination of water and wastewater. American Public Health Association, Washington, 1985.

39. Costello, A. M. and Lidstrom, M. E., Molecular characterization of functional and phylogenetic genes from natural populations of methanotrophs in lake sediments. Appl. Environ. Microbiol., 1999, 65(11), 5066-5074.

40. Bourne, D. G., Mcdonald, I. R. and Murell, J. C., Comparison of pmoA PCR primer sets as tools for investigating methanotroph diversity in three Danish soils. Appl. Environ. Microbiol., 2001, 67(9), 3802-3809.

41. Zhang, T. and Fang, H. H. P., Applications of real-time polymerase chain reaction for quantification of microorganisms in environmental samples. Appl. Microbiol. Biot., 2006, 70(3), 281-289.

42. IBM Corp. Released 2011, IBM SPSS Statistics for Windows, Version 20.0, Armonk, NY, IBM Corp.

43. Borken, W., Davidson, E. A., Savage, K., Sundquist, E. T. and Steudler, P., Effect of summer throughfall exclusion, summer drought, and winter snow cover on methane fluxes in a temperate forest soil. Soil Biol. Biochem., 2006, 38(6), 1388-1395.

44. Jang, I., Lee, H. and Kang, H., The response of nitrogen deposition to methane oxidation availability and microbial enzyme activities in forest soils. Environ. Engine. Res., 2010, 15(3), 157161 .

45. Boeckx, P., VanCleemput, O. and Villaralvo, I., Methane oxidation in soils with different textures and land use. Nutr. Cycl. Agroecosys., 1997, 49(1-3), 91-95.

46. Adamsen, A. P. and King, G. M., Methane consumption in temperate and subarctic forest soils: rates, vertical zonation, and responses to water and nitrogen. Appl. Environ. Microbiol., 1993, 59(2), 485-490.

47. Brumme, R. and Borken, W., Site variation in methane oxidation as affected by atmospheric deposition and type of temperate forest ecosystem. Global Biogeochem. Cy., 1999, 13(2), 493-501.
48. Menyailo, O. V. and Hungate, B. A., Interactive effects of tree species and soil moisture on methane consumption. Soil Biol. Biochem., 2003, 35(4), 625-628.

49. Striegl, R. G., Mcconnaughey, T. A., Thorstenson, D. C., Weeks, E. P. and Woodward, J. C., Consumption of atmospheric methane by desert soils. Nature, 1992, 357(6374), 145-147.

50. Saynes, V., Hidalgo, C., Etchevers, J. D. and Campo, J. E., Soil C and $\mathrm{N}$ dynamics in primary and secondary seasonally dry tropical forests in Mexico. Appl. Soil Ecol., 2005, 29(3), 282-289.

51. Bodelier, P. L. E. and Laanbroek, H. J., Nitrogen as a regulatory factor of methane oxidation in soils and sediments. FEMS Microbiol. Ecol., 2004, 47(3), 265-277.

52. Mohanty, S. R., Bodelier, P. L. E., Floris, V. and Conrad, R., Differential effects of nitrogenous fertilizers on methane-consuming microbes in rice field and forest soils. Appl. Environ. Microbiol., 2006, 72(2), 1346-1354.

53. Bodelier, P. L. E., Roslev, P., Henckel, T. and Frenzel, P., Stimulation by ammonium-based fertilizers of methane oxidation in soil around rice roots. Nature, 2000, 403(6768), 421-424.

54. Menyailo, O. V., Abraham, W. R. and Conrad, R., Tree species affect atmospheric $\mathrm{CH}_{4}$ oxidation without altering community composition of soil methanotrophs. Soil Biol. Biochem., 2010, 42(1), 101-107.

ACKNOWLEDGEMENTS. This research work was funded by DST (SERB), Government of India, New Delhi (EMR/2014/000502). Y.B. is grateful to CSIR, New Delhi, India, for the financial assistance in the form of Senior Research Fellowship (SRF). We also thank Coordinator CAS, DST-FIST and PURSE for facilities.

Received 5 February 2019; revised accepted 4 September 2019

doi: $10.18520 / \mathrm{cs} / \mathrm{v} 118 / \mathrm{i} 5 / 750-758$ 